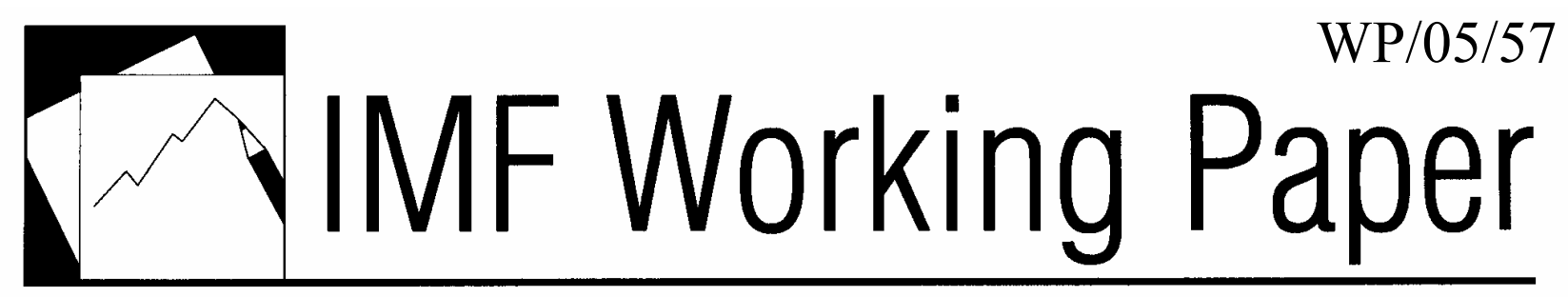

\title{
Government Debt: \\ A Key Role in Financial Intermediation
}

Michael Kumhof and Evan Tanner 


\title{
IMF Working Paper
}

\author{
Research Department
}

\section{Government Debt: A Key Role in Financial Intermediation}

\author{
Prepared by Michael Kumhof and Evan Tanner ${ }^{1}$ \\ Authorized for distribution by Gian Maria Milesi-Ferretti
}

March 2005

\begin{abstract}

\section{This Working Paper should not be reported as representing the views of the IMF.} The views expressed in this Working Paper are those of the author(s) and do not necessarily represent those of the IMF or IMF policy. Working Papers describe research in progress by the author(s) and are published to elicit comments and to further debate.
\end{abstract}

The literature on optimal fiscal policy finds that highly volatile real returns on government debt, for example through surprise inflation, have very low costs. However, policymakers are almost always very apprehensive of this option. The paper discusses evidence concerning features of developing country financial markets that are missing in existing models, and that may suggest why this policy is considered so costly in practice. Most importantly, domestic banks choose to be highly exposed to government debt because the alternative, private lending, is more risky under existing legal and institutional imperfections. This exposure makes banks and their borrowers vulnerable to the government's debt policy.

JEL Classification Numbers: E62; F34

Keywords: Optimal fiscal policy, distortionary taxation, inflation, government debt

Author(s) E-Mail Address: mkumhof@imf.org; etanner@imf.org

\footnotetext{
${ }^{1}$ This paper was prepared for the Festchrift in honor of Guillermo Calvo, which we held at the International Monetary Fund on April 16, 2004. We are grateful to Abdul Abiad and Ashoka Mody, who generously shared their dataset on financial repression with us. Excellent research assistance was provided by Nicolas Amoroso and Wolfgang Harten. All errors are our own.
} 
I. Introduction

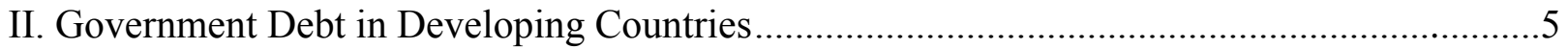

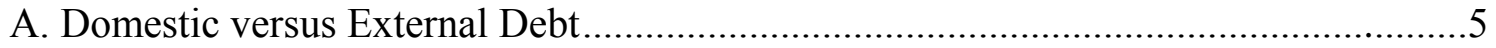

B. Financial Institutions Hold a Large Part of Their Assets in Government Debt ............7

C. The Reason for Large Government Debt Holdings: Legal and Institutional Weaknesses................................................................

D. Government Debt and Further Financial Development:

Private Bond Markets .10

III. Summary and Conclusions

Appendix I

References. 15

Figures

1a. Latin America-Domestic Share of Marketable Government Debt................................ 19

1b. Latin America-Marketable Government Debt to GDP Ratios ...................................... 19

2a. Asia - Domestic Share of Marketable Government Debt .........................................20

2b. Asia - Marketable Government Debt to GDP Ratios .............................................. 20

3a. Other Developing Countries - Domestic Share of Marketable Government Debt .........21

3b. Other Developing Countries - Marketable Government Debt to GDP Ratios ................21

4a. Small Industrialized Countries - Domestic Share of Marketable Government Debt......22

4b. Small Industrialized Countries - Marketable Government Debt to GDP Ratios ............ 22

5a. Scandinavia - Domestic Share of Marketable Government Debt ..............................23

5b. Scandinavia - Marketable Government Debt to GDP Ratios ....................................... 23

6a. Large Industrialized Countries - Domestic Share of Marketable Government Debt ...... 24

6b. Large Industrialized Countries - Marketable Government Debt to GDP Ratios ............ 24

7. Latin American Financial Institutions - Credit to Public Sector/Total Assets ..............25

8. Asian Financial Institutions - Credit to Public Sector/Total Assets..............................25

9. Eastern European Financial Institutions - Credit to Public Sector / Total Assets ........... 26

10. Middle Eastern/African Financial Institutions - Credit to Public Sector/Total Assets ... 26

11. Industrialized Countries Financial Institutions - Credit to Public Sector/Total Assets... 27

12. Small European Countries Financial Institutions - Credit to Public Sector/Total Assets27

13. Government Debt on Balance Sheets and Legal/Institutional Quality .........................28

Table

1. Reserve Requirements 


\section{INTRODUCTION}

Optimally, governments should finance their expenditures such that losses from distortionary taxation are minimized. Some authors have emphasized that such losses might be substantially reduced through the use of state-contingent capital levies on government debt-in bad times, the government defaults outright and/or engineers a debt devaluation through a price level increase. ${ }^{2}$ However, real-world policy debates are not typically cast in such terms. First, bonds with explicit state-contingent returns are rarely available to governments. Second, default or debt devaluation is typically considered to be a policy of last resort, and certainly not as a desirable way to balance the budget. ${ }^{3}$ For example, according to the recent 'stress test' approach to fiscal policy of the International Monetary Fund (2003), a fiscal adjustment should be large enough to preempt inflation, default, or additional adjustment in the future.

Why do policymakers think of debt devaluation so differently from the academic literature? As economists, we typically address such questions by considering various market imperfections. The most popular approach in the literature is the sticky price friction, e.g., Siu (2004), SchmittGrohe and Uribe (2004) and Angeletos (2003). Another is a cash in advance constraint on consumption, as in Nicolini (1998) and Díaz-Giménez, Giovanetti, Marimon and Teles (2003). But among policymakers, the reason that is invariably advanced is the damage that a debt devaluation would do to the domestic financial system. We therefore hypothesize that the difference between academic theory and policy reality is due to several features of financial markets that are absent from existing models, and that are particularly pronounced in developing countries.

Most importantly, financial markets suffer from problems associated with asymmetric information, ${ }^{4}$ and legal and institutional imperfections can make it prohibitively costly and time-

\footnotetext{
${ }^{2}$ See Lucas and Stokey (1983), Chari, Christiano, and Kehoe (1994), and a large subsequent literature surveyed e.g. in Chari and Kehoe (1999). More recent contributions include Angeletos (2002) and Buera and Nicolini (2004).

${ }^{3}$ Such a policy must be unanticipated and credibly on a one-time basis. If it does become unavoidable to resolve a fiscal problem in this way, then the aim of a well-designed IMFsupported fiscal adjustment program is of course to achieve that credibility. The time inconsistency problem associated with such a policy discussed by Calvo (1978) and Calvo and Guidotti (1993) is not considered in this paper.

${ }^{4}$ A related literature employs models of segmented asset markets, e.g., Alvarez, Lucas, and Weber (2001). In such models a subset of agents is unable to trade assets and therefore to smooth consumption over time and states of nature. Instead, state-dependent taxes and transfers (including the inflation tax, in that paper) help them do so. In a similar vein, Shin (2003) develops a model of fiscal policy with heterogeneous agents. To us it seems that the key issue is the ability of firms to continue to obtain financing. Studies such as Kaminsky and Reinhart (1999) have shown that (debt) devaluations in developing countries are almost invariably accompanied by a banking collapse that causes a severe output contraction.
} 
consuming to take security interests in real estate or movable property that could help to overcome these asymmetries. In this case fiscal policy, and especially a predictable debt management that provides a safe asset, can be crucial in order to support at least some intermediation and to thereby help overcome barriers between borrowers and lenders. In essence, safe government debt facilitates financial intermediation by serving a collateral like function. In developing countries, as we will show, this is reflected in the presence of large amounts of government debt on bank balance sheets. In some cases, government debt is also used as explicit collateral in repurchase agreements - a transaction that requires that government debt be safe. And finally, as is stressed in a large literature on the development of emerging country bond markets, government debt plays an important role as a benchmark for private sector bond markets, which are key to successful overall financial development.

Consider how the above could be incorporated into a simple theoretical model. ${ }^{5}$ Assume that the government issues nominal debt, and levies a proportional tax on labor income to finance a given expenditure flow. Producers need to borrow capital from an intermediary who requires that a certain minimum fraction of the loan must be covered by government debt as collateral. Then fiscal policy creates two distortions. First, the positive labor tax rate implies a suboptimal work effort. Second, the collateral requirement implies a suboptimal level of capital. The first distortion usually makes a highly volatile inflation rate desirable in order to engineer statecontingent real returns on debt. But the second distortion does the opposite, because an inflation-induced erosion of the public debt stock would affect the economy's ability to intermediate capital. A welfare maximizing government therefore faces a trade-off. And that trade-off may suggest why defaults and debt devaluations are so rarely used in practice. ${ }^{6}$

International Monetary Fund (2002) illustrates the practical importance of this reasoning. This study finds that in each of the four recent government debt restructurings it examines, the key consideration in delaying a restructuring for as long as possible has been fear of the resulting damage to domestic banks, especially given their potential to spread and amplify the negative effects of a restructuring throughout the economy.

This line of thinking can draw on several parts of Guillermo Calvo's inspiring body of work. A key element of Calvo (1988) is that surprise inflation is not costless, thereby giving rise to a trade-off between taxation and inflation. The paper implements this by way of an exogenous cost function for inflation. And Calvo and Vegh $(1990,1995)$ assume that bonds enter the utility function. While the application of that technology in those papers was different, this holds the key to a more formal modeling of costly unanticipated inflation, such as the approach suggested in the previous paragraph.

${ }^{5}$ See Kumhof (2004) for more details.

${ }^{6}$ Depending on the parameterization of the model, it may also address another problem of the optimal fiscal policy literature, which is that in many of those models only very small stocks of government debt can be sustained in equilibrium. 
In this paper, we provide evidence that is relevant to the above discussion. We show that the type of debt that is important for the effect of default and debt devaluation on domestic financial systems, domestically held debt, is of greater and growing importance than external debt for almost every single emerging market country. This in itself is interesting, given that most of the interest in the context of emerging market debt has focused on external debt, to which very different economic criteria apply in a default scenario.

Next, to address the question of government debt in financial intermediation, we show that in most of these countries banks hold an extremely high proportion of their assets in government debt. To relate this finding to financial market imperfections, we show that there is a positive relationship between such holdings and a comprehensive index of legal and institutional imperfections, containing measures of difficulties in contract enforcement, in registering property, and in obtaining credit. Finally, we provide detailed evidence that suggests that the high bank holdings of government debt are no longer due to financial repression in all but a handful of the larger developing countries - they are indeed the result of a choice to hold the safe asset.

\section{Government DebT In DeVeloping Countries}

\section{A. Domestic Versus External Debt}

The literature on optimal fiscal policy has mainly used closed economy models, and the analysis has mainly been applied to large industrialized countries such as the United States. On the other hand, when it comes to government debt in developing countries the literature has used open economy models, and has been almost exclusively concerned with external or sovereign debt. External debt default is clearly considered costly in practice ${ }^{7}$, but in the literature that cost is not generally held to include direct negative effects on the domestic financial system. The question arises as to whether this exclusive preoccupation with external debt is still justified in today's developing countries. As we will now show, with very few exceptions including most notably Argentina, the answer to that question is no.

Our main data source for this exercise is Bank for International Settlements (BIS) (2004), which aggregates comprehensive data on individual securities issues obtained from financial market sources. $^{8}$ As explained in the data appendix, the split of the BIS data into domestic and international securities is very conservative in what it classifies as a domestic security. The only securities classified as domestic are issues by residents, targeted at resident investors, in

\footnotetext{
${ }^{7}$ It also involves an effect that does not arise under a domestic debt default, and that goes in the opposite direction: A wealth transfer from foreigners.

${ }^{8}$ This dataset excludes non-marketable debt. For more comprehensive measures of government debt, a disaggregation into domestic and international debt is not available at the frequency and country coverage required for this study.
} 
domestic currency. As the BIS data set excludes Brady bonds, we merge it with a JP Morgan data set on outstanding Bradies.

The results are presented in Figures 1-6, which plot quarterly data from 1994Q1 through 2003Q4. For each group of countries we first present the domestic share of marketable government debt and then the ratio of marketable government debt to GDP. We present developing countries, and industrialized countries for comparison.

The broad trends for the marketable debt-to-GDP ratios for industrialized and developing countries are quite different. Most industrialized countries started with relatively high ratios around 50 percent (obviously with wide deviations in either direction) that have not exhibited a long-term growth trend, a recent slight increase having been preceded by a decline in the 1990s. The well-known exception is Japan. Developing countries typically had much lower marketable debt-to-GDP ratios of around 20 percent in the mid-1990s, but with few exceptions they have since exhibited a positive growth trend. More importantly, the growth trend in the domestic part of that debt has been even stronger, as Figures 1a, 2a, and 3a illustrate. In almost all major developing countries the share of domestic debt has risen and now represents in excess of 70 percent of overall debt. ${ }^{9}$ This is remarkable in view of the conservative criteria used for classifying debt as domestic. The only major exceptions to this trend are countries that have experienced severe financial crises accompanied by large devaluations and consequent reductions in the real value of domestic debt. But the only cases where this has kept the domestic debt share well below 50 percent until the present day are Russia and Argentina. ${ }^{10}$ Mexico (in 1995) and Thailand (in 1997) also experienced such episodes but have since returned to domestic debt shares of over 70 percent. In these four cases the large devaluations that eroded nominal domestic debt were accompanied by severe banking crises and output contractions, with recoveries taking several years (see Kaminsky and Reinhart (1999)). The above provides ample evidence to justify our interest in domestically held debt in developing countries. $^{11}$

In the following subsections, we discuss some economic roles that government debt might play in a developing economy. We emphasize throughout how such roles would be diminished if the government employed state-contingent capital levies on debt. One key idea is that stable government debt management may facilitate bank-based financial intermediation, especially in an environment with a weak legal and institutional infrastructure. In addition to that,

\footnotetext{
${ }^{9}$ The overall size of emerging local bond markets at the end of 2002 was four times the size of those countries' foreign currency external debt (see IMF(2004)).

${ }^{10}$ The latter is a special case because its commitment to a currency board left little incentive to develop a domestic currency bond market.

${ }^{11}$ Similar evidence for many smaller developing countries is presented in Cabbar and Jonasson (2004) for South Asia, Del Valle (2002), and Del Valle and Batlay (2002a) for the Middle East and North Africa, and Batlay and del Valle (2002b) for Eastern Europe and Central Asia.
} 
practitioners emphasize that stable government debt markets are the backbone for further development of financial markets beyond a bank-based system. Given that well-developed financial intermediation is held to have positive effects on capital accumulation and growth, this implies important real effects of fiscal and debt policy.

\section{B. Financial Institutions Hold a Large Part of Their Assets in Government Debt}

The major holders of government debt in developing countries are banks (and other lenders) and pension funds. The role of the latter is still relatively minor, with a few notable exceptions such as Chile, and so are private securities markets. Financial intermediation is therefore highly dependent on banks. As we will now show, banks hold a very large proportion of their assets in government debt, which means that stable debt management becomes critical for financial stability.

Figures 7-12 show the exposures of national banking systems to government debt in developing and developed economies. We define that exposure as the average ratio (1998-2002) of financial institutions' net credit to the government ${ }^{12}$ to their total assets. See the data appendix for further detail. In industrialized countries, where the fiscal situation is mostly very robust and government debt therefore extremely safe, that ratio is typically around 10 percent, whereas in developing countries ratios of 20-40 percent are very common, and even ratios above 50 percent are observed in some of the largest developing countries. In such an economy, a government that contemplates a debt devaluation is faced with the insolvency of its banking system, because the typical bank capitalization ratio is less than 10 percent of assets. This is indeed exactly what happened in Argentina, where Perry and Serven (2002) conclude that "...the roots of the [Argentinean] crisis lie in the ... rigid exchange rate regime, the fragile fiscal position, and the hidden vulnerability of the banking system behind its strong facade...." During the protracted negotiations that eventually led to Argentina's massive default, it was a key consideration that a large government default would seriously harm the banking system.

\section{The Reason for Large Government Debt Holdings: Legal and Institutional Weaknesses}

Large holdings of government debt by banks in developing countries have in the past been the result of financial repression. However, as first stressed by Reinhart, Rogoff and Savastano (2003), forced holdings of government debt by captive financial institutions are gradually disappearing and being replaced by government debt securities issued at market interest rates. ${ }^{13}$ The evidence presented in Table 1 confirms that view. ${ }^{14}$ Reserve requirements no longer exist in

${ }^{12}$ Unlike the BIS measure used above, this includes non-marketable government debt.

${ }^{13}$ Caprio (1999) also discusses evidence to this effect.

${ }^{14}$ We are extremely grateful to Abdul Abiad and Ashoka Mody for sharing with us the historic information contained in Table 1, which can also be found in Abiad (2004). The 2004 entries were collected by contacting IMF staff economists. 
several key developing countries, and have been falling in others, to the point that they are actually no longer binding. Binding reserve requirements seem to mostly affect pension funds in some countries, because they are prevented from investing abroad and have only limited domestic investment possibilities (see also World Pension Association (2002)).

The large holdings of government debt by banks must therefore be largely voluntary. On the other hand, as we have seen, government debt in developing countries is in fact mostly lower than in industrialized countries. The main problem is therefore that banks do not lend very much, or in other words that important segments of an economy are unable to borrow, or can only obtain credit with great difficulty. De Soto $(2000)^{15}$ suggests that the culprit for this problem is poorly developed laws and institutions. Potential borrowers cannot collateralize their loans with physical assets or enforce lending contracts and security provisions in the courts. Fleisig $(1996,1998)$ quantifies some of the resulting differences in lending behavior between industrialized and developing countries, and emphasizes that the major problem is the inability to use movable capital as collateral, with mortgages being subject to fewer problems. He mentions that in the United States 70 percent of all loans are secured by collateral, and almost 50 percent of all credit is secured by movable collateral. Movable capital represents 67 percent of the U.S. industrial capital stock and 75 percent of gross business investment (Asian Development Bank (2000)). It is obviously critical for businesses to be able to use such capital as collateral. But in Argentina they are unable to do so. Only around 10 percent of all bank credit is secured at all, and practically none of it is secured by movable collateral. This is because, as described by Fleisig $(1996,1998)$, creation of security interests especially over movable property is difficult, costly and uncertain, perfection and registration is not effectively possible, and enforcement is slow and expensive. As a result, U.S. banks relying predominantly on movable collateral are seen as safe by both bank examiners and the public, while Argentinean banks that do so are not. They will therefore have to curtail the amount of such lending and seek to bolster their balance sheet through safer investments, including holdings of government debt. Asian Development Bank (2000) reports that when debtors can offer acceptable collateral, private creditors offer six to eight times more credit, two to ten times longer maturity, and 30 to 50 percent lower interest rates. The effect on interest rates is also described by Fleisig (1998), who compares loans against movable property in the United States and Argentina. Because in Argentina movable security is considered almost irrelevant to the recoverability of a loan, a loan for agricultural machinery (for example) has lending rates of around 60 percent. Of the enormous difference of that rate to a corresponding US lending rate, only about one sixth is explained by macroeconomic risk and one-tenth by the general difficulty of collecting against security (including mortgages). A full three quarters of the difference is due to problems with the legal framework for secured transactions against movable property. This is a more general problem for both Latin America, as discussed in Garro (1998), and for Asia, as discussed in Asian Development Bank (2000) and Cranston (1998). These authors find that banks generally prefer real estate (and personal guarantees). The macroeconomic consequences of such problems include an inefficient savings allocation, an inefficient allocation of capital (with a preference for assets that can be used as collateral), fragile banks

\footnotetext{
${ }^{15}$ Pagano (2001) contains similar arguments.
} 
highly exposed to credit risks, an inability to use securitization for risk diversification (thereby increasing the dependence on fragile banks), and negative effects on equity because small and start-up businesses, who do not own land, find it almost impossible to obtain credit. All of this has negative effects on real economic activity. Fleisig (1998) cites country studies that put just the cost of defective systems of lending security at 5-10 percent of annual GNP, with the cost of reforming such systems a small fraction of that. The major international financial institutions have therefore in recent years paid increasing attention to these issues, as exemplified by European Bank for Reconstruction and Development (2000) ${ }^{16}$, Asian Development Bank (2000), and World Bank (2004).

It should be added that, in developing countries, even real estate security is often subject to numerous problems, including cost, time delays, difficulties in establishing priority in the absence of efficient registries, and other issues. Cranston (1998) explains that in several Asian countries much of the land remains communally held according to customary law, ruling out its use as collateral. Fleisig (2002) mentions that in Latin America most of the land is not titled, and existing registries are rudimentary.

Legal and institutional imperfections are therefore of critical importance for business, but at the same time they are hard to quantify. The work of La Porta, Lopez de Silanes, Shleifer and Vishny (1998) has therefore been extremely valuable in creating cross-sectional country indices for the quality of law and institutions affecting businesses. It is now available through World Bank (2004) in the form of updated indicators, ${ }^{17}$ on the basis of, among others, the papers by Djankov, McLiesh, and Shleifer (2004) and Djankov, La Porta, Lopez de Silanes and Shleifer (2003). For the purpose of this study we are interested specifically in the factors responsible for segmented credit markets, which are represented by three factors. The first is "getting credit," describing the quality and accessibility of credit information and the quality of collateral and bankruptcy laws. The second is "enforcing contracts," measuring the cost and time delays in the collection of an overdue debt. And the third is "registering property," measuring the cost and time delays of transferring title to real estate.

We compute an overall raw index for all countries in our sample by attaching equal weights to all three categories. ${ }^{18}$ Our final index ranges between 0 and 100, with $0 / 100$ for the countries with the worst/best raw index. We create another index for the importance of debt on financial institutions' balance sheets, as discussed above, with $0 / 100$ for the lowest/highest government debt to total assets ratio among all countries in the sample. Figure 13 plots these two indices against each other. The results are striking. There is a very strong negative relationship between

\footnotetext{
16 The EBRD's Model Law on Secured Transactions of 1994 has been used to help several Eastern European transition economies in the redesign of their legal systems.

${ }^{17}$ The dataset is available at http:// rru. worldbank.org/ DoingBusiness/ ExploreTopics/ GettingCredit/CompareAll.aspx.

${ }^{18}$ Our qualitative results are not dependent on the details of the weighting scheme.
} 
the quality of law and institutions and the amount of government debt which financial institutions choose to hold on their balance sheets. Almost all the countries in the top left corner of Figure 13 are developing countries, and almost all in the bottom right are industrialized (Chile does best among developing countries).

Financial institutions with highly risky and largely unsecured lending books are very vulnerable to macroeconomic shocks. Their high holdings of government debt are generally an attempt to offset the credit risk inherent in private credit with government debt, which bears no credit risk. This is recognized by the Basle rules for capital adequacy which give a much lower risk weighting (zero) to such debt, even if the debtor is an emerging market government. The safety of banks' government debt portfolio is a precondition for even the limited amount of private sector lending that does take place. In such countries prudent management of public debt is critical for the health of the banking system, and using state-contingent returns on government debt would be highly damaging.

\section{Government Debt and Further Financial Development: Private Bond Markets}

As we have argued, prudent management of government debt is important to safeguard fragile domestic banking systems. But financial development in the long run benefits greatly from moving beyond a purely bank-based system to include not only a stock market but also a longterm private bond market. And here again, as emphasized by World Bank and IMF (2001), ${ }^{19}$ the government bond market plays a critical role because it is the backbone of most fixed income securities markets.

Herring and Chatusripitak (2000) present the key arguments for why private bond markets matter for financial development, stability and growth, ${ }^{20}$ and show how legal and institutional factors have impeded the development of private bond markets in Asia. The lack of developed bond markets in developing countries has in recent years also been a major theme for the international financial institutions, including the Inter-American Development Bank (Castellanos (1998), Reinstein (2002), del Valle (2002)), Asian Development Bank (2002), World Bank-IMF (2001), and policymakers in individual countries. ${ }^{21}$ The Asian Bond Market Initiative (Rhee (2004)) is a concerted effort to develop bond markets across that region.

Underdeveloped bond markets make the pricing of credit risks and equities harder because of the absence of a benchmark yield curve. Derivatives markets cannot develop, making the diversification of risk exposures harder. Fewer savings are utilized, and borrowers face higher borrowing costs and shorter maturities (potentially leading to foreign borrowing and thereby resulting in foreign exchange risks), and banks become too large relative to the overall financial

${ }^{19}$ See Chapter 1, page 3, Table 1.1 .

${ }^{20}$ Similar arguments are presented by Fry (1997).

${ }^{21}$ For example, Kang, Kim and Rhee (2004) discuss Korea, and Asian Development Bank (2002) discusses a number of Asian countries in great detail. 
sector, thereby making the economy more vulnerable to crises because of its dependence on a small number of institutions.

Herring and Chatusripitak (2000) identify two major prerequisites for the development of bond markets. The first is the legal and institutional infrastructure mentioned in the previous subsection. The second, already mentioned above as a key concern in World Bank and IMF (2001), is a deep, liquid government bond market. As we have seen, legal problems restrict even bank based private sector lending, and clearly they do the same to bond-based lending. But while it is important to remove those weaknesses, this is a time-consuming process, and in the meantime a stable government bond market is all the more important and can help overcome at least some of the problems caused by those weaknesses. In several developing countries that have still not tackled their legal frameworks effectively, development of the government bond market has nevertheless started to support a private bond market, at least to strong borrowers that are relatively less dependent on collateral.

A government debt market does this first by putting in place a basic financial infrastructure including laws, institutions, products, services, repo and derivatives markets, and second by playing a role as an informational benchmark. A single private issuer of securities would never be of sufficient size to generate a complete yield curve, and his securities would not be nominally riskless because only the government has the power to print domestic currency. The government, through the government debt market, can therefore provide a public good to financial markets, but only under two further conditions. First, macroeconomic volatility, especially inflation volatility, must be low so that a nominal yield curve is informative about the real cost of borrowing. State-contingent inflation would interfere with this goal, and experience confirms this - the volatility in Brazil in 1999 and in Argentina in 2001/2 were major impediments to the further development of their local financial markets (del Valle (2002)). And second, the government must issue a sufficient volume of debt. For this latter reason, during the era of shrinking U.S. public debt (the late 1990s and early 2000s), some observers expressed concern that it would be more difficult to conduct monetary policy in a smaller government debt market (Reinhart, Sack and Heaton (2000), Fleming (2000)). ${ }^{22}$ Similarly, for developing countries Herring and Chatusripitak (2000) conclude that the goal of developing a robust bond market may conflict with the goal of minimizing the cost of government borrowing if a government with fiscal surpluses decides to issue government debt and invest the proceeds in foreign securities in order to provide liquidity, as Hong Kong SAR has done in recent years.

We have seen that government debt plays two key roles. It provides infrastructure and acts as an informational benchmark in securities markets. And on the balance sheets of financial institutions it is, to depositors, a form of security that increases their willingness to have their

\footnotetext{
${ }^{22}$ Not everyone shared this concern for the United States, where financial markets are so deep that some substitutes may be found, especially the abundant issues by government-sponsored enterprises. But Herring and Chatusripitak (2000) stress that the same is not true for developing countries. This is precisely because there the historic lack of developed public debt markets has been an impediment to the growth of private financial markets.
} 
funds intermediated in a generally risky environment. As such, it informally acts as collateral. However, government debt can also play a more direct role as collateral in wholesale securities markets. In particular, it plays a critical role in managing risks in derivatives markets, payment and settlement systems, and in the market for repurchase agreements. Bank for International Settlements (2001) shows that there has been an enormous increase in such collateralized transactions in recent years.

Under a repurchase agreement, a market participant sells a security while simultaneously agreeing to repurchase it in the future. Such a transaction functions as a secured loan. The party purchasing the security makes funds available to the seller while holding that security as collateral. In virtually every financial market worldwide, the only form of security acceptable for repo transactions is government debt, due to its low or zero risk and high liquidity. Because repo markets require quite well-developed financial markets, they generally arise at a later stage of development. We nevertheless found sizable repo markets in Brazil and Mexico, using as a criterion Bankscope bank balance sheet data to express the stock of outstanding repo loans as a fraction of total assets. In Brazil that ratio is around 7 percent, and in Mexico around 5 percent in 2002/03. Other sizable markets exist in the Philippines, Poland, and India.

\section{Summary AND CONCLUSIONS}

Does state-contingent inflation (or default) on government debt represent an optimal way to conduct fiscal policy in response to shocks? This paper makes an attempt to understand the very different replies to this question given by the theoretical literature on optimal fiscal policy on the one hand, and by experienced practitioners on the other hand. Many contributions to the theoretical literature advocate what we have referred to as debt devaluations (in response to negative shocks), while practitioners only think of it as a last resort, to be avoided at almost all cost. The emphasis in this paper is on understanding the thinking of practitioners, particularly decision makers in developing countries, by presenting some pertinent data. We show that debt devaluations are likely to have very negative effects on financial intermediation in developing countries, because their banks are highly exposed to government debt and at the same time face much higher risks in private sector lending because of weak legal and institutional infrastructures. Keeping government debt a safe investment for banks is critical to support the already low financial intermediation that does exist. It is also critical to support further improvements in financial intermediation, away from banks and towards securities markets. Many countries that have not, or have been unable to, follow this advice have experienced serious lending crunches and recessions, and have set back the development of their financial markets by years.

It would be very beneficial to further develop the theory of optimal fiscal policy against the background of these arguments, as this would greatly enhance its usefulness to applied policy analysis. In doing so, great inspiration can be drawn from the work of Guillermo Calvo, who has made several key contributions to this literature. 


\section{Domestic Versus External Debt}

The data were obtained from Bank for International Settlements (2004), which follows the following classification system for domestic versus external/international securities:

\begin{tabular}{|l|c|c|}
\hline & Issues by & Issues by \\
& Residents & non-residents \\
\hline In domestic currency, targeted at resident investors & Domestic & International \\
\hline In domestic currency, targeted at non-resident investors & International & International \\
\hline In foreign currency & International & International \\
\hline
\end{tabular}

Note that the classification covers the borrower side of securities issues, not the actual ownership. This system is very conservative in what it classifies as a domestic security. ${ }^{23}$ Issues by non-residents targeted at domestic investors, whether in domestic or foreign currency, are invariably classified as international, although many if not most holders will be domestic. The same is true for issues in domestic currency targeted at foreign investors, because it is well known that the ultimate holders of developing countries domestic currency debt are in many cases domestic residents. ${ }^{24}$ Bank for International Settlements (2004) also states that notes and money market instruments issued by non-residents in domestic currency and in domestic markets are not included due to lack of data, which again biases results against domestically held debt. The opposite bias results from another missing debt class, Brady bonds, but we remedy this by merging the BIS data set with a JP Morgan data set on outstanding Brady bonds, using the Merrill Lynch (1994) guide for classification of securities.

\section{Bank Holdings of Government Debt}

We define the exposure of banks to government debt as the following ratio:

(Financial institutions' net credit to government) / (financial institutions' net total assets).

\footnotetext{
${ }^{23}$ Notice that limiting the attention to securities is necessary for practical purposes, but a more complete picture would also consider non-marketable government obligations. These include on the domestic side a variety of spending commitments and outstanding debt balances, and on the international side concessional lending from governments and international financial institutions, as well as syndicated bank loans.

${ }^{24}$ Another source of bias is that local issues in foreign currency are generally classified as international. But here exceptions are made by BIS for Argentina, Peru, and the Philippines.
} 
The percentage figures are computed from the IMF's International Financial Statistics, and are averages for 1998-2002, except for countries in the euro area, where 1999-2003 was used. The numerator is the sum of all entries representing net credit to the public sector by deposit money banks, other banking institutions and nonbank financial institutions (the latter series do not exist for all countries). The denominator is the sum of the net total assets of these three groups, after canceling out credit items between them. To obtain the net figures we deduct from both numerator and denominator the sum of all entries representing credit by the public sector to these institutions. Crisis years are excluded from the computation of averages as follows: Argentina 2002, Indonesia 1998. 


\section{REFERENCES}

Abiad, A., 2005, “A New Database of Financial Reforms,” IMF Working Paper (forthcoming).

Alvarez, F., Lucas, R.E. Jr. and Weber, W.E., 2001, "Interest Rates and Inflation,” American Economic Review 91(2), pp. 219-25.

Angeletos, G.-M., 2002, "Fiscal Policy with Noncontingent Debt and the Optimal Maturity Structure," Quarterly Journal of Economics 117(3), pp. 1105-31.

— 2003, "Optimal Fiscal and Monetary Policy," NBER Macroeconomics Annual 2003, Cambridge MA: National Bureau of Economic Research.

Asian Development Bank, 2000, "Secured Transactions Law Reform in Asia: Unleashing the Power of Collateral," Law and Policy Reform at the ADB, Vol. II.

— 2001, Government Bond Market Development in Asia.

Bank for International Settlements, 2001, "Collateral in Wholesale Financial Markets: Recent Trends, Risk Management and Market Dynamics," Committee on the Global Financial System Working Group.

— 2004, "Guide to the International Financial Statistics," BIS Papers No. 14.

Buera, F. and Nicolini, J.P., 2004, "Optimal Maturity of Government Debt without State Contingent Bonds," Journal of Monetary Economics 51(3), pp. 531-54.

Cabbar, D. and Jonasson, T., 2004, "Regional Snapshot of Government Bond Markets, South Asia \& Asia Pacific," The World Bank.

Calvo, G.A., 1978, "On the Time Consistency of Optimal Policy in a Monetary Economy," Econometrica 46(6), pp. 1411-28.

— 1988, "Servicing the Public Debt: The Role of Expectations," American Economic Review 78, pp. 647-71.

Calvo, G.A. and Guidotti, P.E., 1993, “Optimal Maturity of Nominal Government Debt: An Infinite Horizon Model,: International Economic Review 33(4), pp. 895-919.

Calvo, G.A. and Vegh, C.A., 1990, "Interest Rate Policy in a Small Open Economy: The Predetermined Exchange Rates Case,” IMF Staff Papers 37(4), pp. 753-76.

- 1995, "Fighting Inflation with High Interest Rates: The Small Open Economy Case under Flexible Prices", Journal of Money, Credit and Banking 27, pp. 49-66. 
Caprio, G. Jr., 1999, "Review of S. Fry: Emancipating the Banking System and Developing Markets for Government Debt," Journal of Economic Literature 37(4), pp. 1723-25.

Castellanos, J., 1998, "Developing Government Bond Markets," The Inter-American Development Bank, Working Paper IFM-111.

Chari, V.V., Christiano, L. and Kehoe, P.J., 1994, "Optimal Fiscal Policy in a Business Cycle Model,” Journal of Political Economy 102(4), pp. 617-52.

Chari, V.V., and Kehoe, P.J., 1999, "Optimal Fiscal and Monetary Policy," Chapter 26 in Taylor, J.B. and Woodford, M., eds., Handbook of Macroeconomics, Volume 1C, Elsevier.

Cranston, R., 1998, "Credit Security and Debt Recovery: Law's Role in Reform in Asia and the Pacific," in Norton, J.J. and Andenas, M., eds., Emerging Financial Markets and Secured Transactions, International Economic Development Law, Volume 6, London, The Hague, Boston: Kluwer Law International.

Del Valle, C., 2002, "Developing Government Securities Markets—A Framework," Financial Sector Development, The World Bank.

Del Valle, C. and Batlay, M., 2002a, "Regional Snapshot of Middle East and North African Government Bond Markets, " Financial Sector Development, The World Bank.

— 2002b, "Regional Snapshot of Government Bond Markets of Eastern Europe and Central Asia," Financial Sector Development, The World Bank.

De Soto, H., 2000, The Mystery of Capital: Why Capitalism Triumphs in the West and Fails Everywhere Else, New York: Basic Books.

Díaz-Giménez, J., Giovanetti, G., Marimon, R. and Teles, P., 2003, "Nominal Debt as a Burden on Monetary Policy," CREA Barcelona Working Paper \# 8.

Djankov, S., McLiesh, C. and Shleifer, A., 2004, "Private Credit Around the World," Working Paper, Department of Economics, Harvard University, July 2004.

Djankov, S., La Porta, R., Lopez-de-Silanes, R. and Shleifer, A., 2003, “Courts,” Quarterly Journal of Economics 118, pp. 453-517.

European Bank for Reconstruction and Development, 2000, "Secured Transactions: Ten Years of Legal Reform," Law in Transition, Autumn 2000.

Fleisig, H.W., 1996, "Secured Transactions: The Power of Collateral," Finance and Development (June), pp. 44-46. 
1998, "Economic Functions of Security in a Market Economy," in Norton, J.J. and Andenas, M., eds., Emerging Financial Markets and Secured Transactions, International Economic Development Law Volume 6, London, The Hague, Boston: Kluwer Law International.

— 2002, "Microenterprises and Collateral," Center for the Economic Analysis of Law, CEAL Issues Brief, No. 2 (September).

Fleming, M.J., 2000, "Financial Market Implications of the Federal Debt Paydown," in Brookings Papers on Economic Activity:2 (Brookings Institution), pp. 221-51.

Fry, M.J., 1997, Emancipating the Banking System and Developing Markets for Government Debt. London and New York: Routledge.

Garro, A.M., 1998, "Difficulties in Obtaining Secured Lending in Latin America: Why Law Reform Really Matters," in Norton, J.J. and Andenas, M., eds., Emerging Financial Markets and Secured Transactions, International Economic Development Law, Volume 6, London, The Hague, Boston: Kluwer Law International.

Herring, R.J. and Chatusripitak, N., 2000, "The Case of the Missing Market: The Bond Market and Why It Matters for Financial Development,” ADB Institute Working Paper 11.

International Monetary Fund, 2002, "Sovereign Debt Restructurings and the Domestic Economy_Experience in Four Recent Cases," Policy Development and Review Department.

International Monetary Fund, 2003, "Sustainability Assessments-Review of Application and Methodological Refinements," Policy Development and Review Department, http://www.imf.org/external/np/pdr/sustain/2003/061003.pdf.

__, 2004, Emerging Local Securities and Derivatives Markets, World Economic and Financial Surveys.

Kaminsky, G. and Reinhart, C.M., 1999, "The Twin Crises: The Causes of Banking and Balance of Payments Crises," American Economic Review 89(4), pp. 473-500.

Kang, K., Kim, G. and Rhee, C., 2004, "Developing the Government Bond Market in Korea: History, Challenges, and Implications for Asian Countries," Mimeo, Presentation at Asia Economic Panel (AEP), Columbia University, 7-8 October, 2004.

Kumhof, Michael, 2004, "Fiscal Crisis Resolution: Taxation versus Inflation,” Working Paper, Stanford University.

La Porta, R., Lopez-de-Silanes, F., Shleifer, A. and Vishny, R., 1998, "Law and Finance," Journal of Political Economy 106(6), pp. 1113-55. 
Lucas, R.E. Jr. and Stokey, N., 1983, "Optimal Fiscal and Monetary Policy in an Economy Without Capital," Journal of Monetary Economics 12, pp. 55-93.

Merrill Lynch, 1994, "The 1995 Guide to Brady Bonds."

Nicolini, J.P., 1998, "More on the Time Consistency of Optimal Monetary Policy," Journal of Monetary Economics 41, pp. 33-50.

Pagano, M., 2001, ed., Defusing Default -Incentives and Institutions. Washington, DC: Johns Hopkins University Press.

Perry, G. and Serven, L., 2002, "La Anatomia de Una Crisis Multiple: Que Tenia Argentina de Especial y Que Podemos Aprender de Ella (with English summary)," Desarrollo Economico 42(167), pp. 323-375.

Reinhart, C.M., Rogoff, K.S. and Savastano, M.A., 2003, "Debt Intolerance,: Brookings Papers on Economic Activity, pp. 1-74.

Reinhart, V., Sack, B. and Heaton, J., 2000, “The Economic Consequences of Disappearing Government Debt," Brookings Papers on Economic Activity 2, pp. 163-220.

Reinstein, A., 2002, "Issues in Building Corporate Money and Bond Markets in Developing Market Economies," Working Paper, IFM Division, Inter-American Development Bank.

Rhee, C., 2004, “Asia Bond Market Initiative: Progress and Future Directions," Presentation at the International Monetary Fund (October).

Schmitt-Grohe, S. and Uribe, M., 2004, "Optimal Fiscal and Monetary Policy under Sticky Prices," Journal of Economic Theory 114(2), pp. 198-230.

Shin, Y., 2003, “Optimal Fiscal Policy with Incomplete Markets,” Working Paper, Department of Economics, University of Wisconsin, Madison.

Siu, H.E., 2004, "Optimal Fiscal and Monetary Policy with Sticky Prices,” Journal of Monetary Economics 51(3), pp. 575-607.

World Bank and IMF, 2001, Developing Government Bond Markets: A Handbook.

World Bank, 2004, Doing Business in 2004: Understanding Regulation, World Bank and Oxford University Press.

World Pension Association, 2002, "Investment Restrictions to Pension Funds." 
Figure 1a. Latin America - Domestic Share of Marketable Government Debt

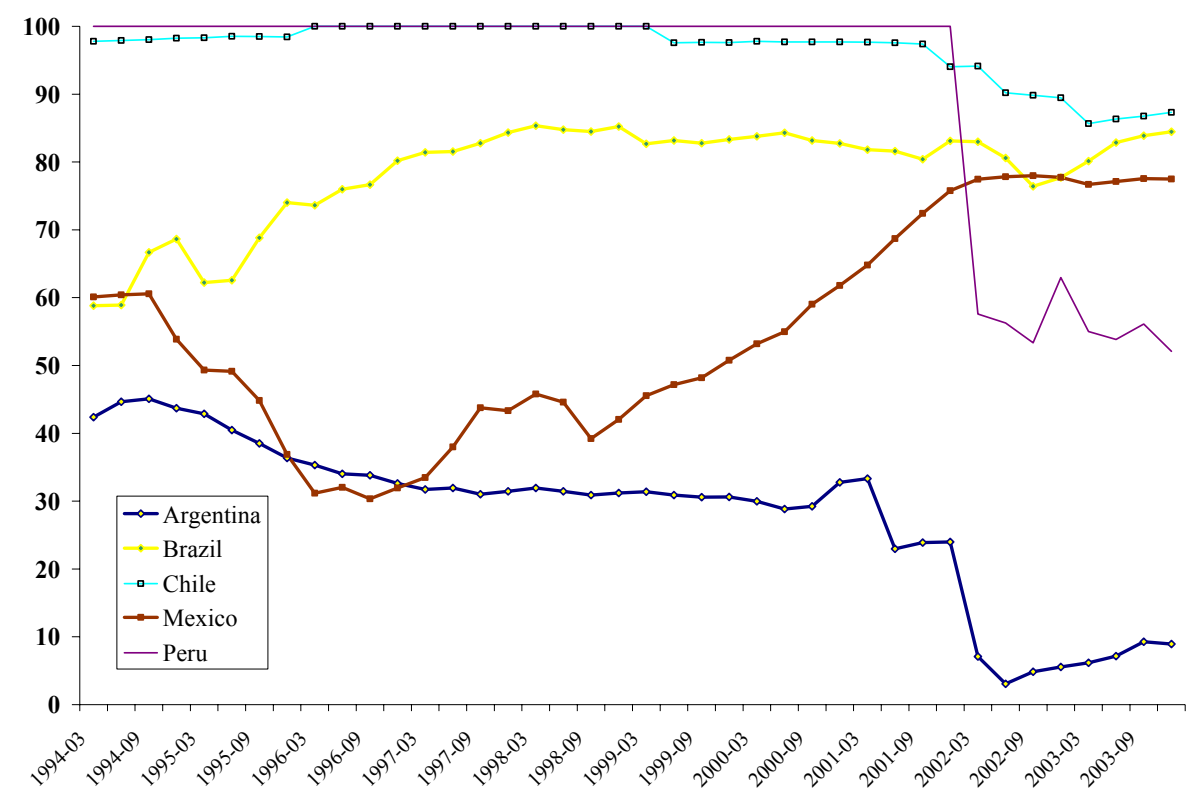

Figure 1b. Latin America - Marketable Government Debt to GDP Ratios

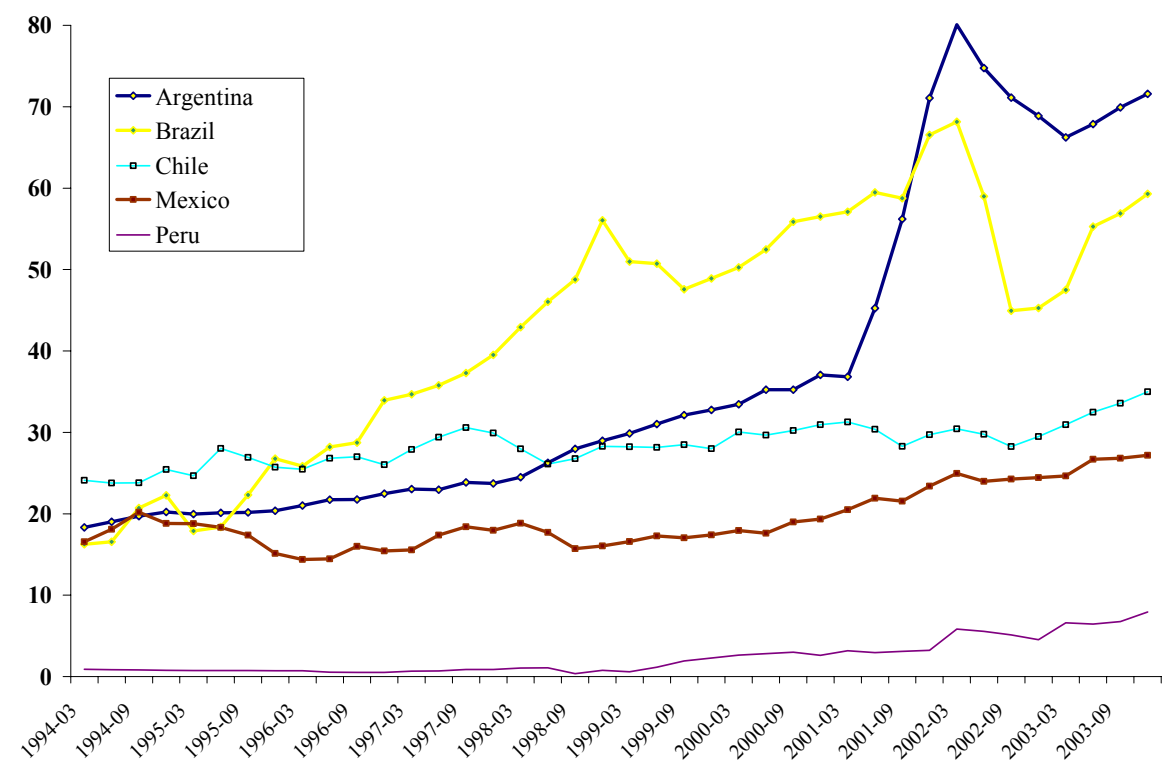


Figure 2a. Asia - Domestic Share of Marketable Government Debt

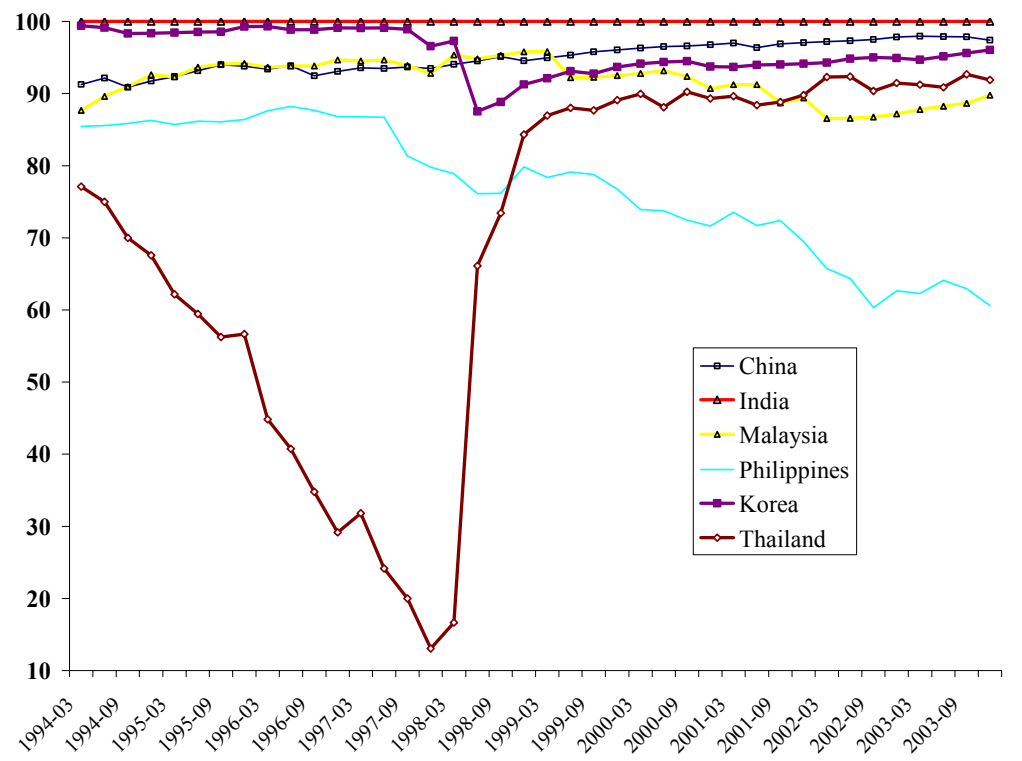

Figure 2b. Asia - Marketable Government Debt to GDP Ratios

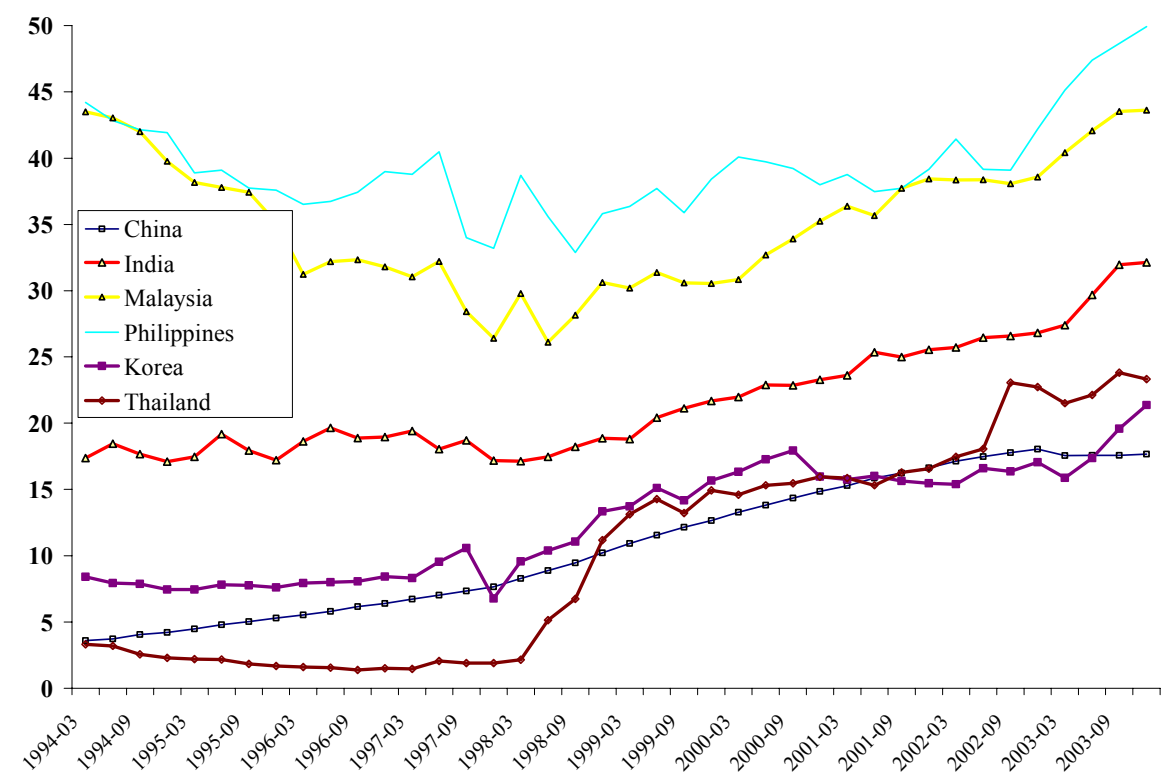


Figure 3a. Other Developing Countries - Domestic Share of Marketable Government Debt

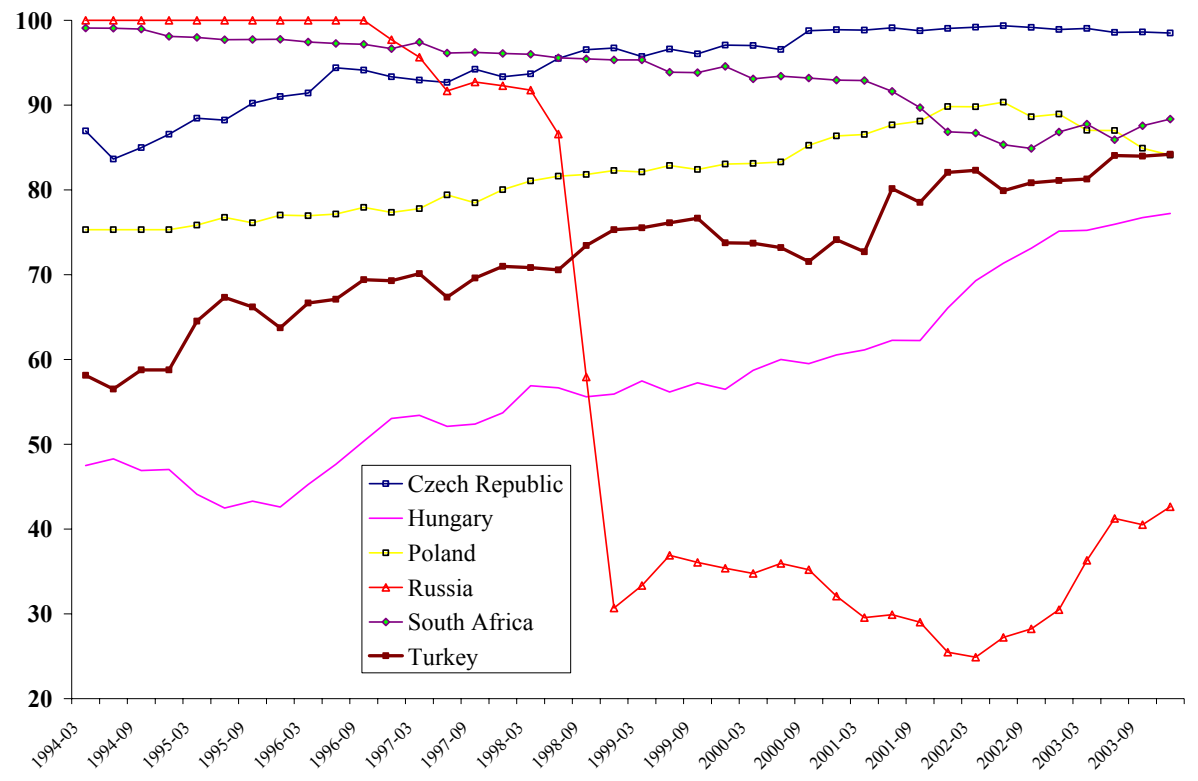

Figure 3b. Other Developing Countries - Marketable Government Debt to GDP Ratios

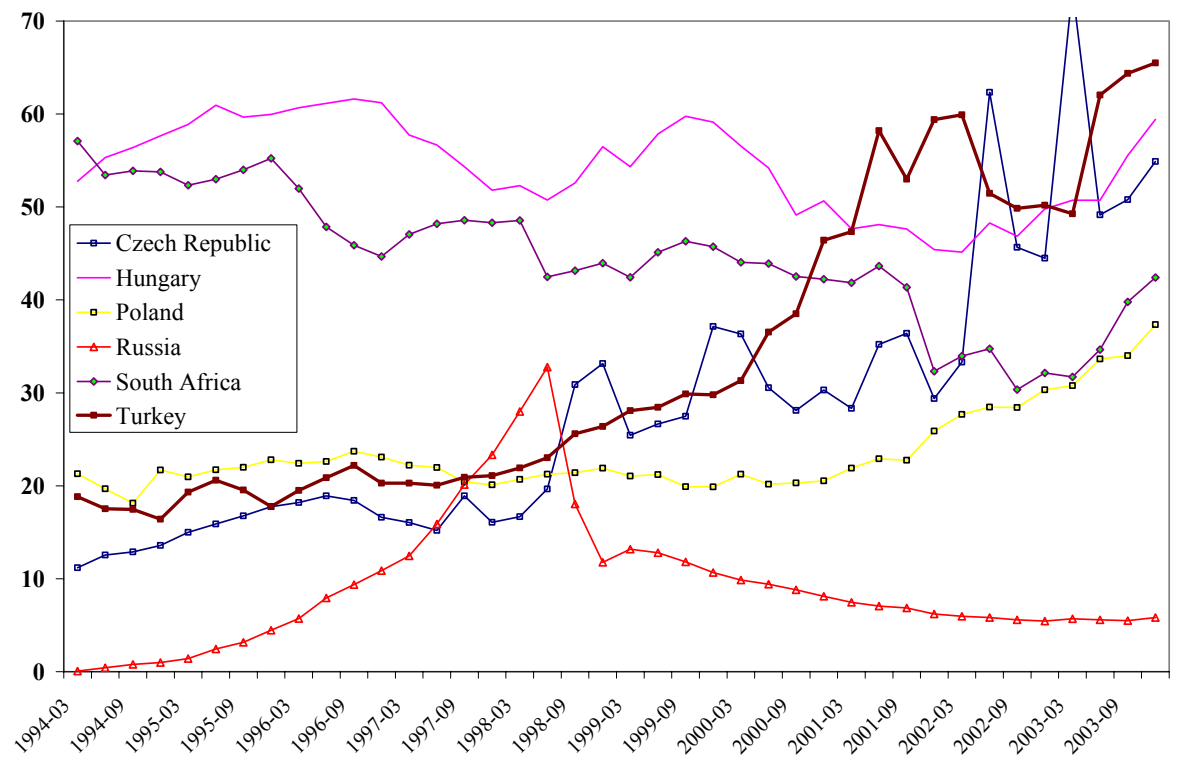


Figure 4a. Small Industrialized Countries - Domestic Share of Marketable Government Debt

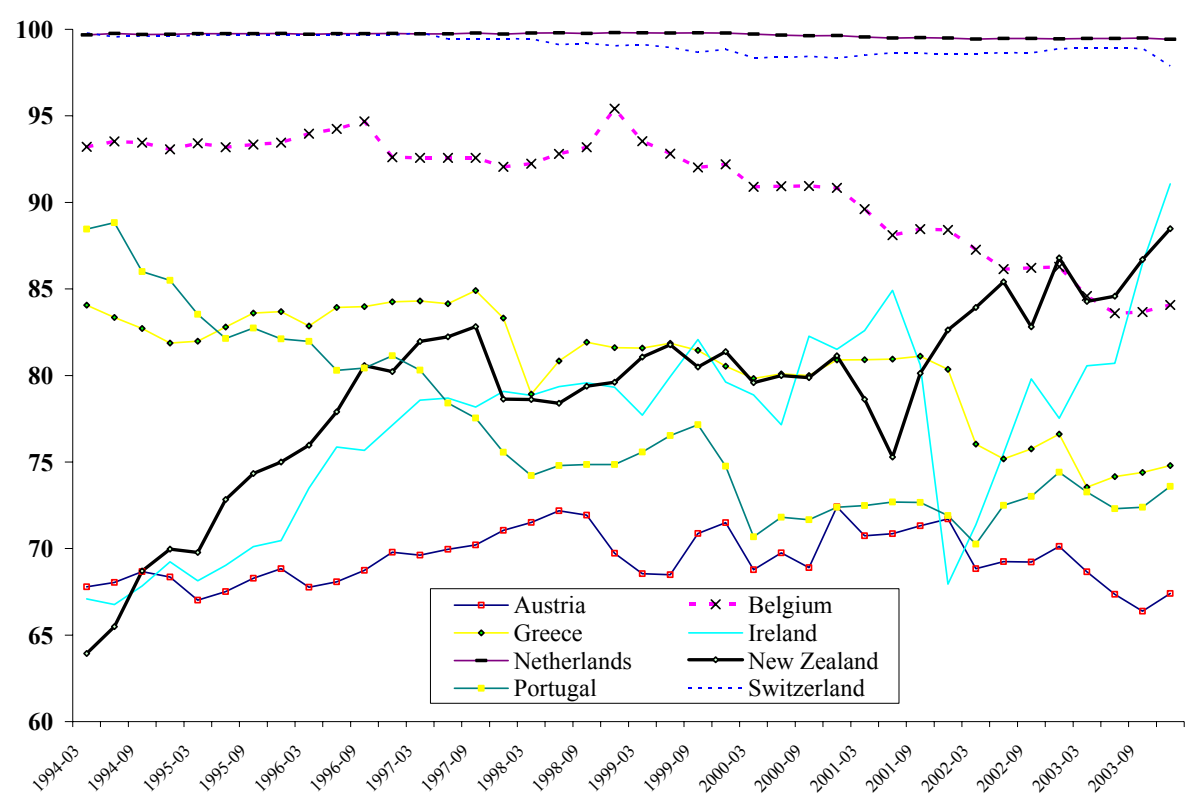

Figure 4b. Small Industrialized Countries - Marketable Government Debt to GDP Ratios

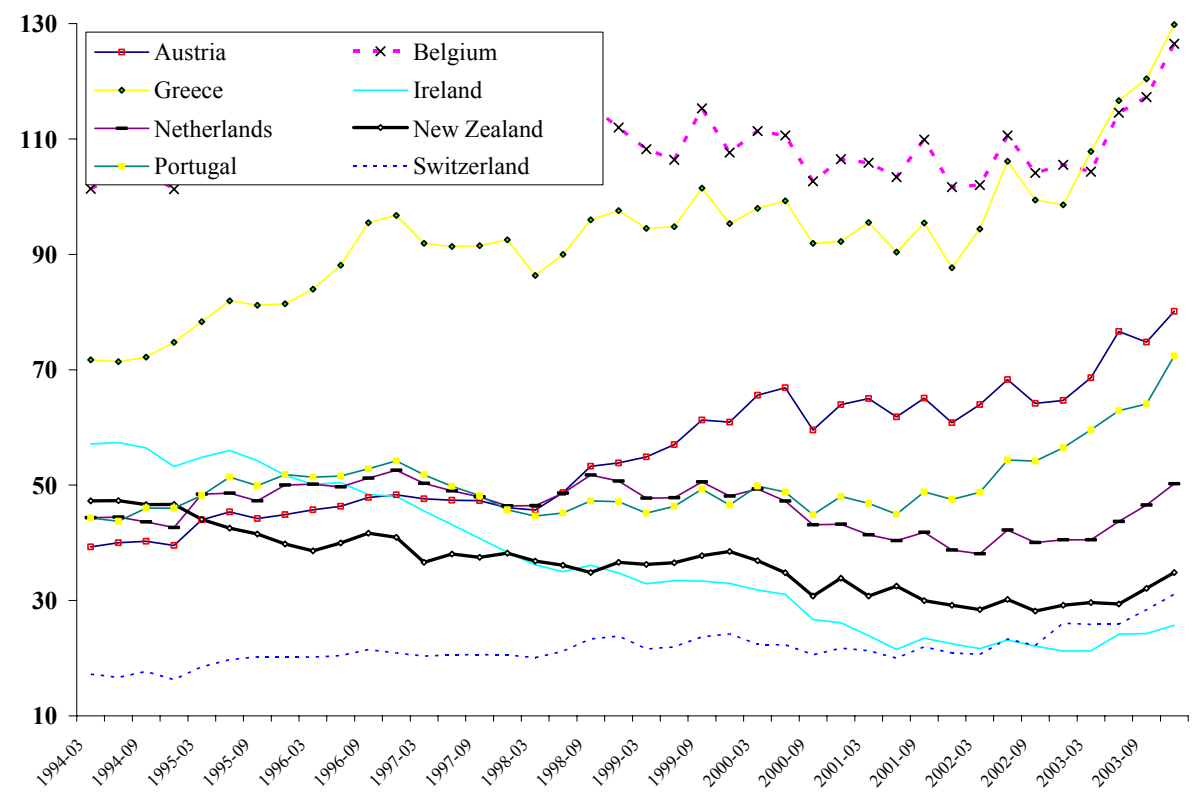


Figure 5a. Scandinavia - Domestic Share of Marketable Government Debt

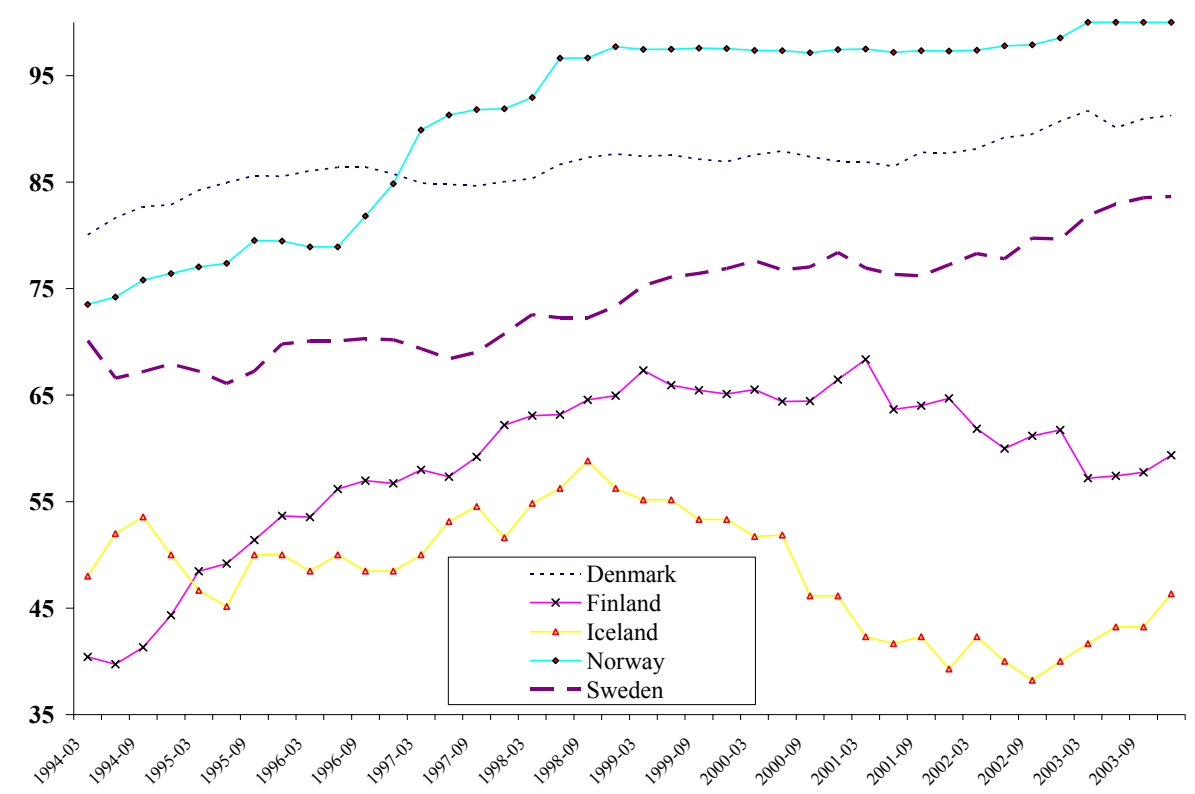

Figure 5b. Scandinavia - Marketable Government Debt to GDP Ratios

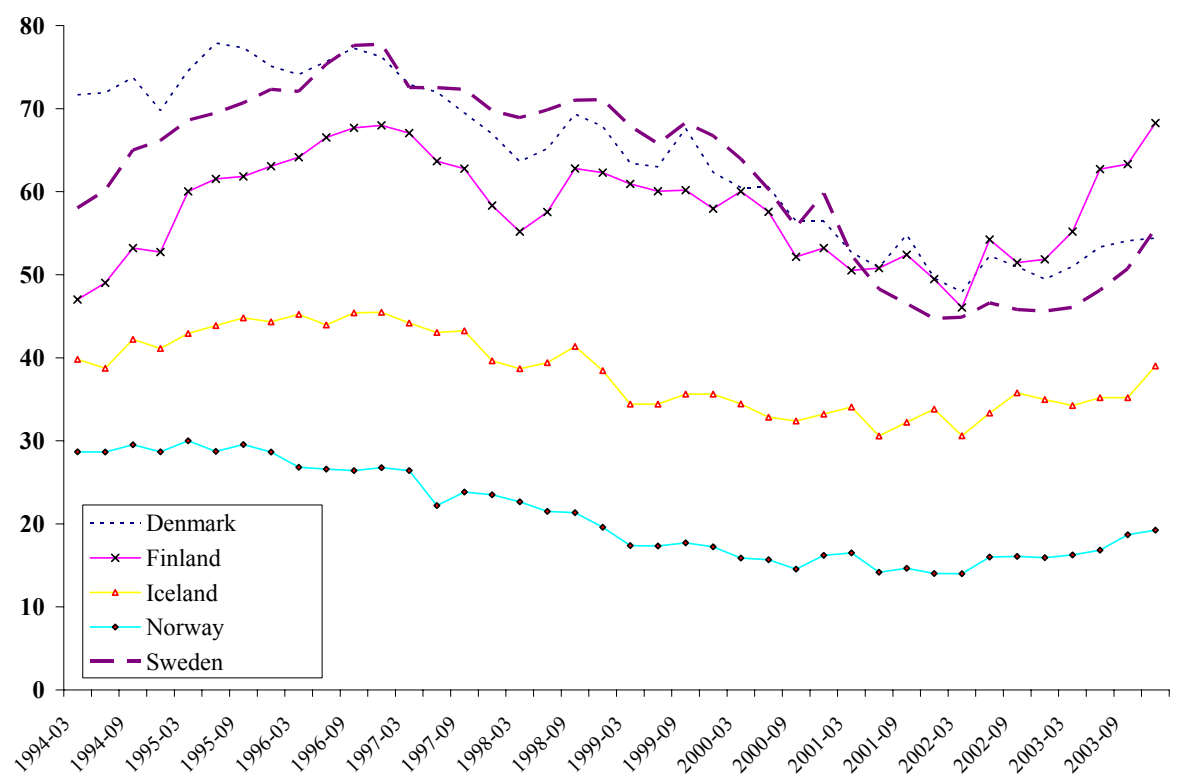


Figure 6a. Large Industrialized Countries - Domestic Share of Marketable Government Debt

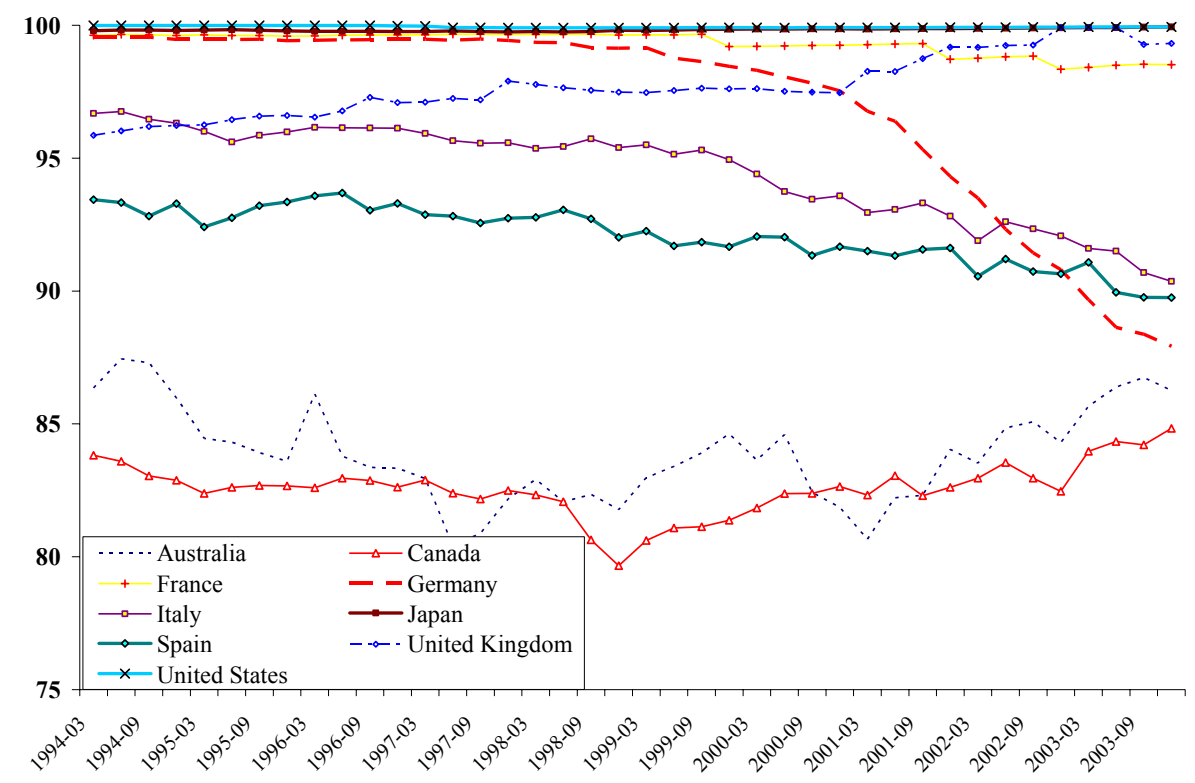

Figure 6b. Large Industrialized Countries - Marketable Government Debt to GDP Ratios

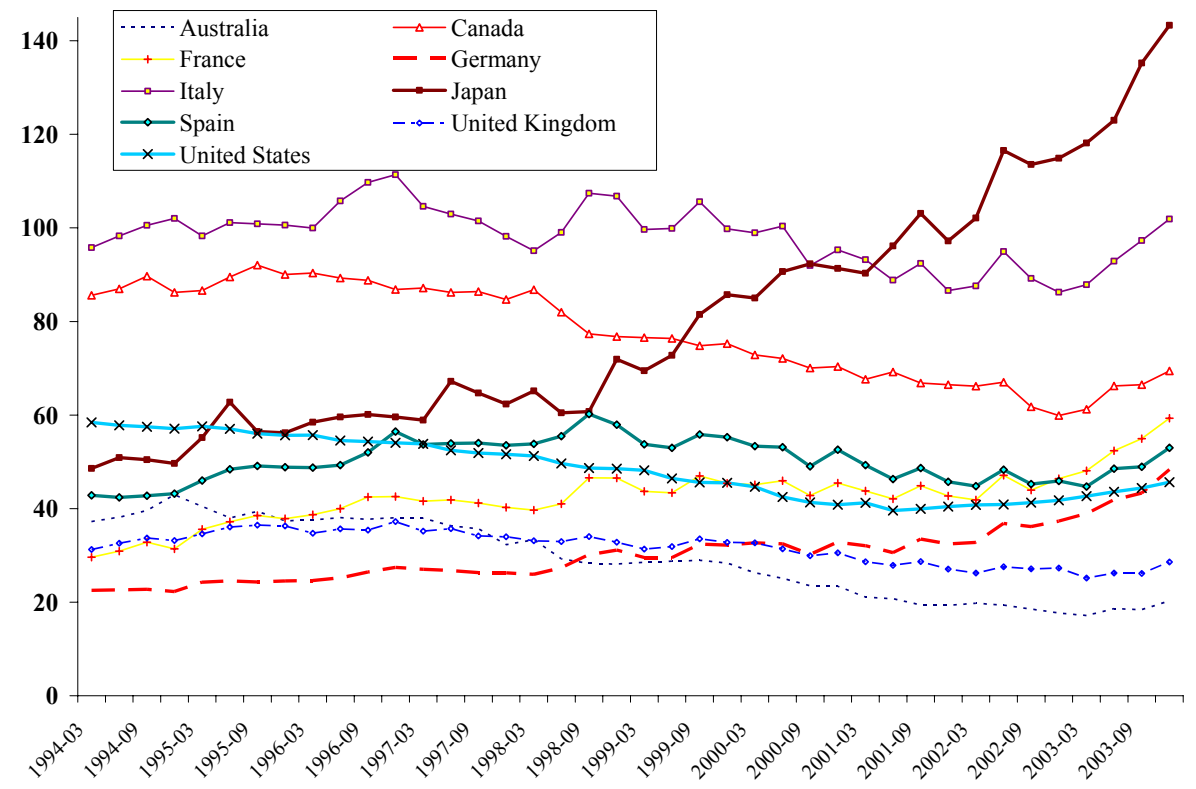


Figure 7. Latin American Financial Institutions - Credit to Public Sector / Total Assets

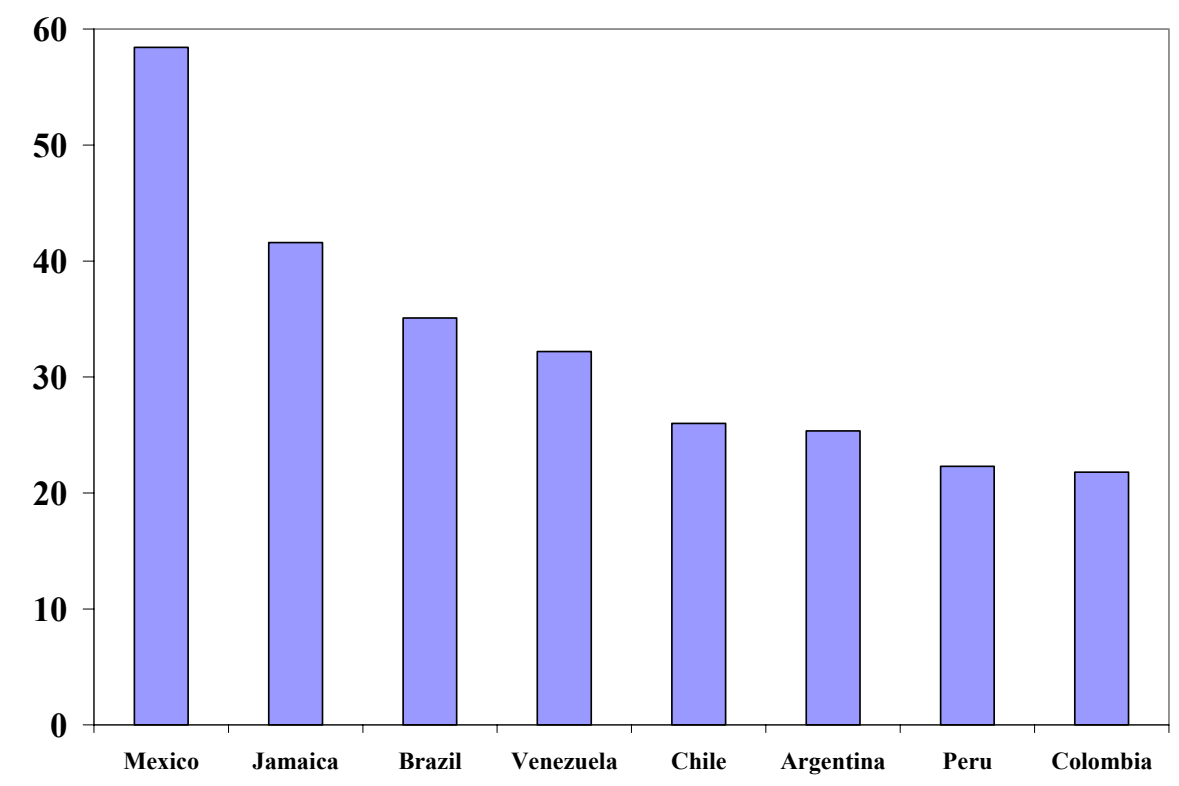

Figure 8. Asian Financial Institutions - Credit to Public Sector / Total Assets

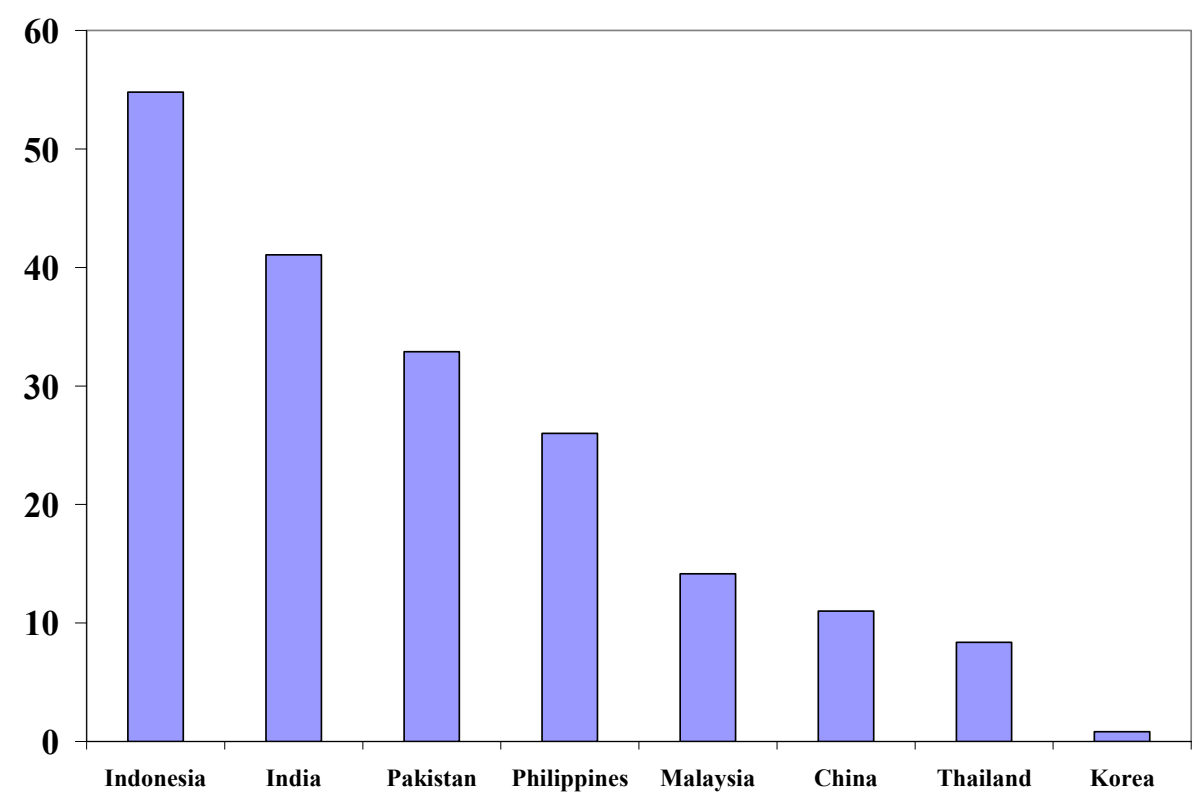


Figure 9. Eastern European Financial Institutions - Credit to Public Sector / Total Assets

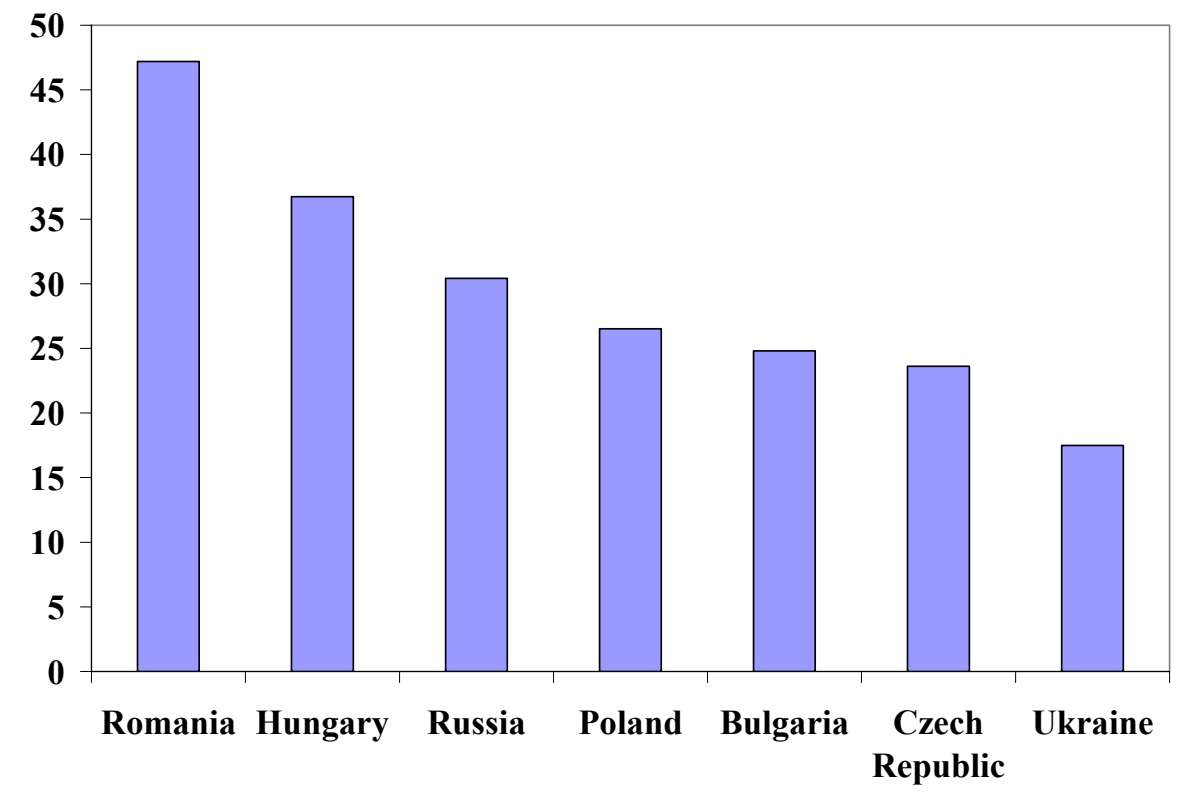

Figure 10. Middle Eastern/African Financial Institutions - Credit to Public Sector / Total Assets

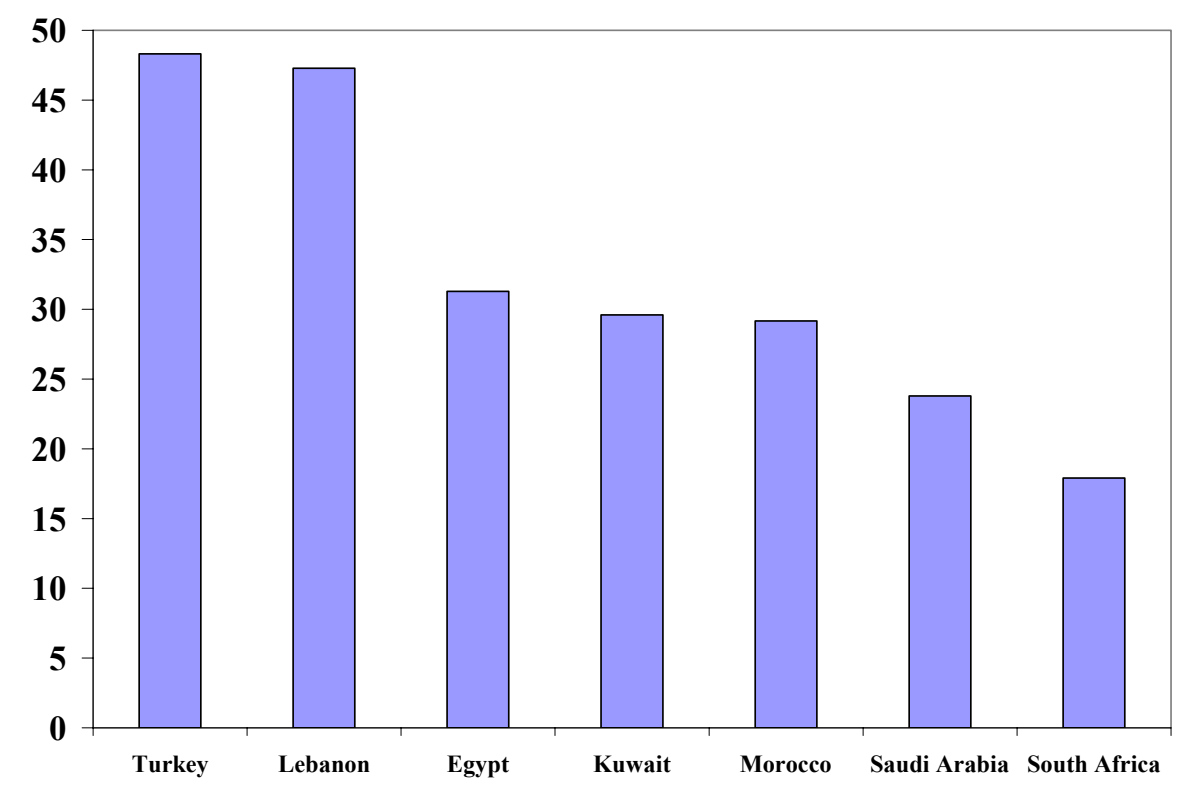


Figure 11. Industrialized Countries Financial Institutions - Credit to Public Sector / Total Assets

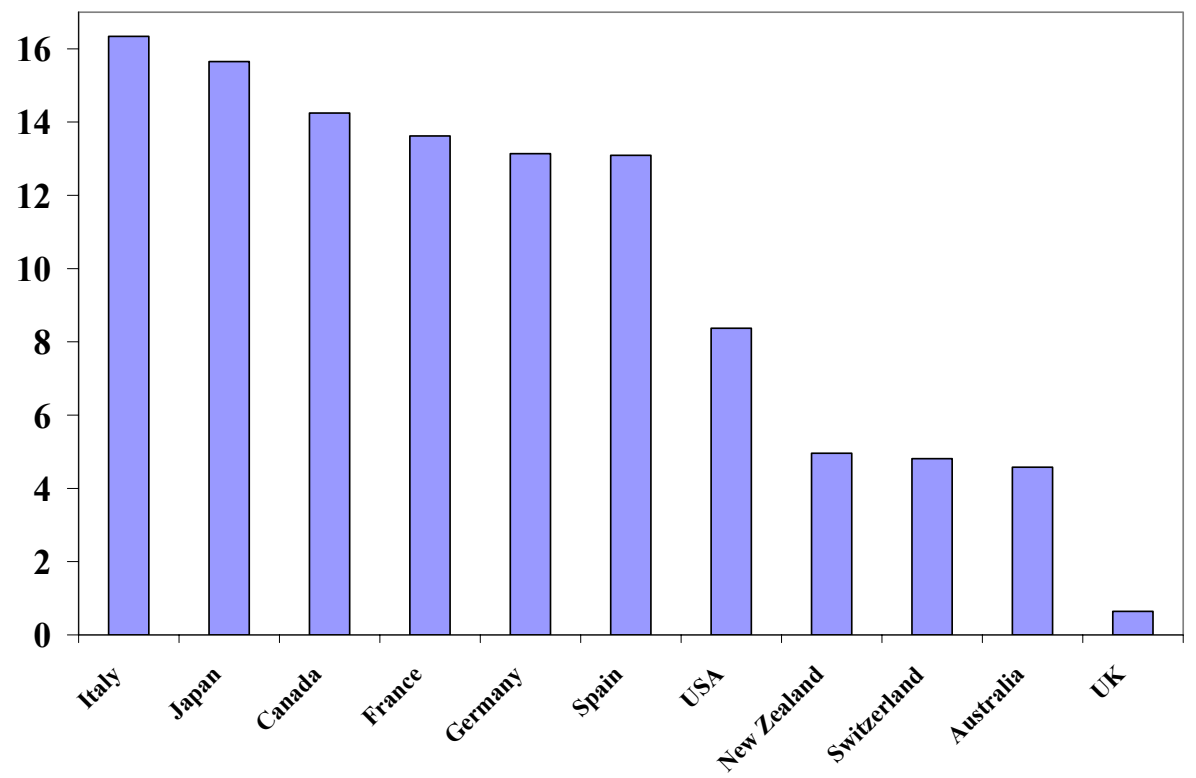

Figure 12. Small European Countries Financial Institutions - Credit to Public Sector / Total Assets

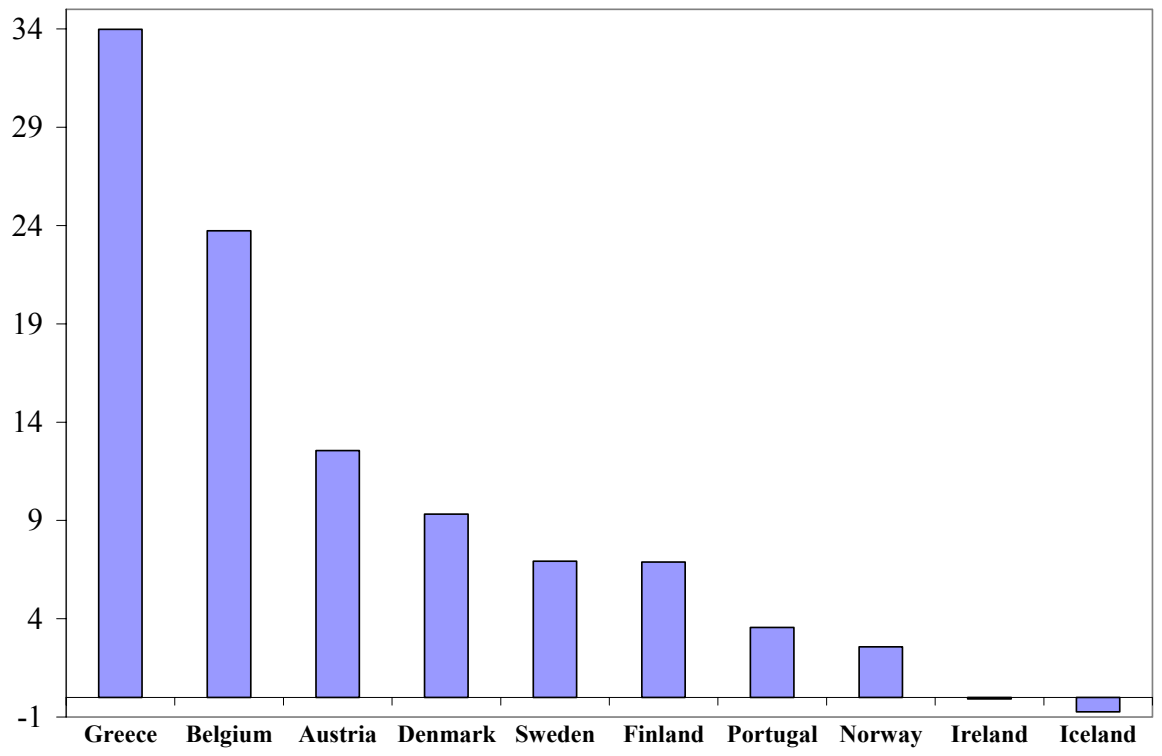


Figure 13. Government Debt on Balance Sheets and Legal/Institutional Quality

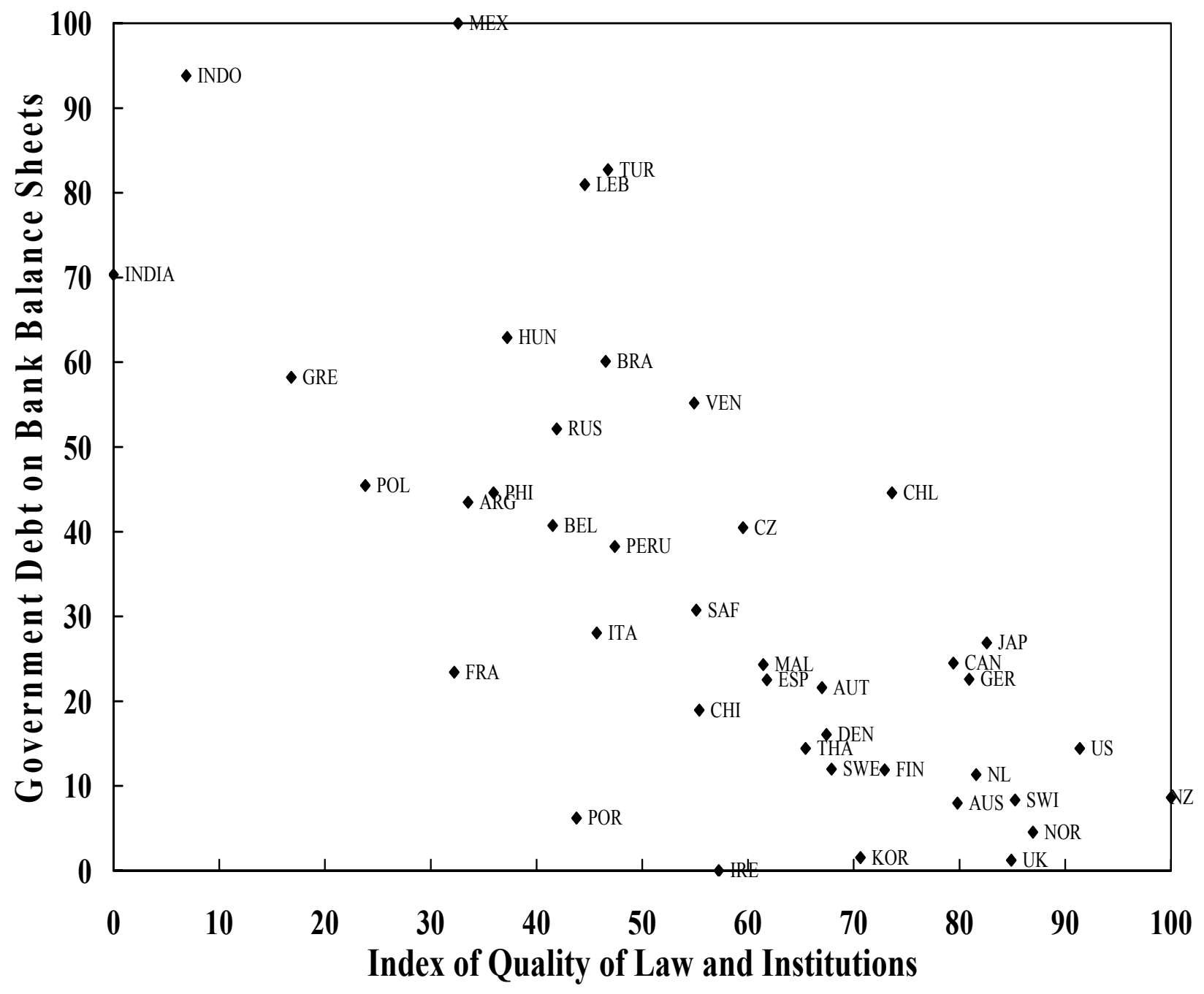


Table 1. Reserve Requirements

\begin{tabular}{|c|c|c|}
\hline \multirow{5}{*}{$\begin{array}{l}\text { Country } \\
\text { Brazil }\end{array}$} & Year & Description ( $R R=$ reserve requirement) \\
\hline & 1996 & RR remains over 80 percent on demand deposits. \\
\hline & 1999 & $\begin{array}{l}\text { April: RR on demand deposits up to } 100 \text { percent, on other acc. claims up to } \\
60 \text { percent. October: RR on bank deposits reduced from } 65 \text { to } 45 \text { percent }\end{array}$ \\
\hline & 2001 & RR on demand deposits 45 percent, RR on time deposits 10 percent. \\
\hline & 2004 & No de jure RR (source: IMF Staff Economists). \\
\hline China & 2004 & No de jure RR (source: IMF Staff Economists). \\
\hline \multirow{7}{*}{$\begin{array}{l}\text { Czech } \\
\text { Republic } \\
\text { India }\end{array}$} & 2004 & No de jure RR (source: IMF Staff Economists). \\
\hline & 1990 & Cash reserve ratio (CRR) 10 percent. \\
\hline & 1998 & CRR raised to $10.5 \%$. lowered to 10 percent raised to $11 \%$. \\
\hline & 1999 & CRR lowered to $10.5 \%$, then to 10 percent and to 9 percent in November. \\
\hline & 2000 & CRR lowered to 8 percent. \\
\hline & 2001 & CRR lowered to 7.5 percent. \\
\hline & 2004 & $\begin{array}{l}\text { Statutory Liquidity Ratio (SLR): RR of } 25 \text { percent in the form of government } \\
\text { bond holdings. }\end{array}$ \\
\hline \multirow[t]{2}{*}{ Indonesia } & 1999 & No RR. \\
\hline & 2004 & No de jure RR (source: IMF Staff Economists). \\
\hline Jamaica & 2004 & $\begin{array}{l}\text { Actual holdings of government bonds far exceed RR (source: IMF Staff } \\
\text { Economists). }\end{array}$ \\
\hline Korea & 2001 & $\mathrm{RR}=2.9$ percent \\
\hline Lebanon & 2004 & No de jure RR (source: IMF Staff Economists). \\
\hline \multirow[t]{3}{*}{ Mexico } & 1991 & $\begin{array}{l}\text { Liquidity coefficients on foreign currency deposits up to } 50 \text { percent dep. on } \\
\text { maturities. }\end{array}$ \\
\hline & 1995 & Change from a daily zero RR system to cumulative zero RR over 28 day period \\
\hline & 1999 & $\mathrm{RR}=0$ percent \\
\hline \multirow[t]{8}{*}{ Philippines } & 1991 & RR rationalized. \\
\hline & 1993 & RR for bank deposits lowered from 25 to 22 percent. \\
\hline & 1994 & RR lowered to 17 percent. \\
\hline & 1995 & RR lowered to 15 percent \\
\hline & 1997 & RR lowered to 13 percent \\
\hline & 1998 & RR lowered to 10 percent. \\
\hline & 1999 & $\mathrm{RR}=11$ percent for commercial banks, $\mathrm{RR}=0 \%$ for rural and cooperative banks. \\
\hline & 2002 & $\mathrm{RR}=9$ percent \\
\hline Poland & 2004 & No RR on banks. (source: IMF Staff Economists). \\
\hline Russia & 2004 & $\mathrm{RR}=3.5$ percent \\
\hline \multirow[t]{4}{*}{ Turkey } & 1994 & Comprehensive reform of $\mathrm{RR} . \mathrm{RR}=10.8$ percent. \\
\hline & 1995 & $\mathrm{RR}=9.3$ percent. \\
\hline & 1996 & $\begin{array}{l}\mathrm{RR}=8 \text { percent for domestic currency deposits, } \mathrm{RR}=11 \text { percent for foreign } \\
\text { currency. }\end{array}$ \\
\hline & 2004 & $\begin{array}{l}\text { Actual holdings of government bonds far exceed RR (source: IMF Staff } \\
\text { Economists). }\end{array}$ \\
\hline
\end{tabular}

